\title{
ISPITIVANJE MOGUĆNOSTI UKLANJANJA SINTETSKIH BOJA U MIKROREAKTORSKIM SISTEMIMA
}

\author{
INVESTIGATION OF THE POSSIBILITY OF WASTEWATER \\ DECOLORIZATION IN MICROREACTOR SYSTEMS
}

\author{
Ana DAJIĆ' ${ }^{1)}$, Marina MIHAJLOVIĆ1), Dušan MIJIN²), \\ Jovan JOVANOVIĆ(), Mića JOVANOVIĆ ${ }^{2)}$ \\ ${ }^{1)}$ Inovacioni centar Tehnološko-metalurškog fakulteta Univerziteta u Beogradu, Beograd; \\ ${ }^{2)}$ Tehnološko-metalurški fakultet Univerziteta u Beogradu, Beograd \\ aveljasevic@tmf.bg.ac.rs; msavic@tmf.bg.ac.rs; kavur@tmf.bg.ac.rs; \\ j.m.jovanovic@tmf.bg.ac.rs; mica@tmf.bg.ac.rs
}

Boje spadaju u klasu opasnih zagađivača životne sredine. Česta upotreba sintetskih boja u tekstilnoj industriji za posledicu ima velike količine obojene otpadne vode. Pre ispuštanja otpadne vode u recipijent, vodu je potrebno prečistiti i njen kvalitet dovesti do nivoa propisanog zakonom. Procesi prečišćavanja otpadnih voda te vrste nisu jednostavni i podrazumevaju korišćenje raznih hemijskih agenasa, čijom upotrebom se voda dodatno zagađuje. U ranijim radovima, prikazana je uspešnost obezbojavanja otpadne vode iz tekstilne industrije, zagadene sintetskom bojom Reactive Orange 16, mikroreaktorskim stemima upotrebom razblaženih rastvora $\mathrm{NaOCl}$. Ovaj rad bavi se ispitivanjem mogućnosti obezbojavanja simulirane otpadne vode iz tekstilne industrije zagađene sintetskim bojama Basic Yellow28 i Acid Blue 111, u mikroreaktorskim sistemima, korišćenjem razblaženih rastvora $\mathrm{NaOCl}$.

Ključne reči: mikroreaktori; otpadna voda; azo boje; tekstilna industrija;

Dyes are an important class of pollutants. Usage of synthetic dyes in the textile industry as a consequence has high amounts of colored wastewater. Before discharging, colored water has to be treated to achieve quality prescribed by law. Decolorization is a complex process which includes application of different chemical reagents which leads to additional water contamination. Our earlier works showed success in decolorization of wastewater contaminated with Reactive Orange 16. This paper deals with possibility of decolorization of wastewater, contaminated with Basic Yellow 28 and Acid Blue 111, in microreactor system using diluted solution of $\mathrm{NaOCl}$.

Key words: microreactor; waste water; azo dyes; textile industry

\section{Uvod}

Boje spadaju u klasu značajnih zagađujućih materija, a posledica njihove široke upotrebe su velike količine ove zagađujuće supstance u životnoj sredini. Prema materijalu koji se boji, boje delimo na tekstilne boje; boje za kožu; papir i polimerne mase i drugo. Prema rastvorljivosti na rastvorne u vodi i to direktne odnosno supstantivne; reaktivne; kisele; bazne i metal-kompleksne; i nerastvorne u vodi: azoične ili ledene; redukcione; disperzione i boje rastvorne u ulju ili alkoholu. Prema hemijskoj strukturi dele se na nitro ili nitrozo; azo; trifenilmetanske; indigoidne i antrahionske. U literaturi se može pronaći i podela boja u tri opšte grupe na katjonske, anjonske i nejonske boje [1].

C.I. Basic Yellow 28 (BY 28) spada u grupu katjonskih azometinskih boja zbog prisustva azometinske grupe $(-\mathrm{CH}=\mathrm{N})$. Ima najveću primenu u tekstilnoj industriji za bojenje svile i akrilnih vlakana, kao i u kožarskoj industriji. Slika 1 prikazuje sintetsku boju BY 28.

C.I. Acid Blue 111 (AB 111) pripada grupi antrahinonskih boja. Sve komercijalno važne antrahionske boje predstavljaju derivate antrahiona koji je svetlo žute boje. Uvođenjem elektron donorskih supstituenata u molekul dobijaju se boje koje se obično koriste za bojenje vune, a karakteriše ih dobra postojanost na pranje. Slika 2 prikazuje sintetsku boju C.I. Acid Blue 111.

C.I. Reactive Orange 16 (RO16) je iz grupe anjonskih azo boja. Ove boje daju intenzivno obojenje i njihova sinteza polazeći od jeftinih lako dostupnih sirovina nije komplikovana. Karakteriše ih dobra postojanost prema svetlosti i pranju. Slika 3 prikazuje sintetsku boju Reactive Orange 16. 


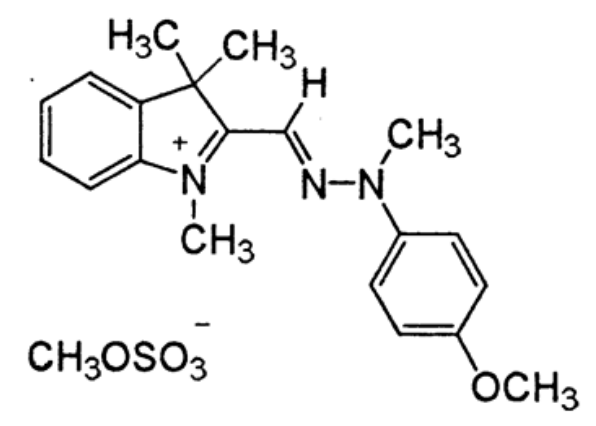

Slika 1. Struktura BY 28<smiles>CCOC(=O)c1ccccc1Cc1ccc(Nc2cc(S(N)(=O)=O)c(N)c3c2C(=O)c2ccccc2C3=O)c(C)c1</smiles>

Slika 2. Struktura AB 111<smiles>CC(=O)Nc1ccc2cc(S(N)(=O)=O)c(N=Nc3ccc(S(=O)(=O)CCOS(=O)(=O)O[Na])cc3)c(O)c2c1</smiles>

Slika 3. Struktura sintetske boje RO 16

Nakon primarnog tretmana koji podrazumeva mehaničko prečišćavanje kojim se uklanjaju plivajuće čestice i čestice koje je moguće staložiti, sledi sekundarno prečišćavanje koje podrazumeva biološko prečišćavanje kojim se uklanjaju rastvorne organske materije, koloidne i netaložive čvrste materije kao i redukcija sadržaja boje u otpadnoj vodi. Tercijarni stepen prečišćavanja podrazumeva uklanjanje azotnih i fosfatnih materija. Završnim, kvaternernim prečišćavanjem uklanja se preostalo opterećenje i vrši se dezinfekcija vode ukoliko je to neophodno [1].

Zbog složene strukture boja, njihovo uklanjanje iz otpadnih voda nije jednostavno a tretman koji se primenjuje zavisi od nekoliko faktora: koncentracije boje, stepena čistoće do koga želimo dovesti vodu na kraju tretmana, opreme i sredstava kojima raspolažemo itd. Uklanjanje sintetskih boja u industriji obično se izvodi primenom fizičko-hemijskih tretmana. Najčešće je to: filtriranje [2], fotokatalitička oksidacija i dekolorizacija [3], ozonizacija [4], mikrobiološka dekompozicija sintetskih boja [5], adsorpcija na različitim organskim i neorganskim materijama [6], koagulacija i flokulacija [7], elektrokoagulacija [8] i elektrohemijska dekolorizacija [9]. Svaka od navedenih metoda rezultira visokim troškovima za opremu i uloženu energiju, formiranjem mulja i nus-proizvoda koji predstavljaju otpad koji bi trebalo dodatno tretirati pre konačnog odlaganja na deponije. Sa ekonomske tačke i sa stanovišta zaštite životne sredine ovo nije povoljna opcija. Atraktivna alternativa ovim metodama je prečišćavanje korišćenjem mikroreaktorskih sistema korišćenjem komercijalno dostupnog sredstva za obezbojavanje $\mathrm{NaOCl}$. Mikroreaktorski sistemi se karakterišu mikrometarskim dimenzijama i radu u kontinualnom režimu što rezultira intenzifikacijom procesa, lakom kontrolom temperature i postizanjem većeg stepena obezbojavanja korišćenjem malih količina reaktanata.

U ranijim radovima Dajić i saradnika [10,11] obrađene su mogućnosti uklanjanja sintetske boje Reactive Orange 16 iz simulirane otpadne vode tekstilne industrije. Cilj istraživanja nije bio potpuno uklanjanje boje iz uzoraka, nego dovođenje kvaliteta otpadnih voda do zadovoljavajućeg nivoa za ispuštanje u vodoprijemnike. Ovaj rad bavi se ispitivanjem mogućnosti prečišćavanja simulirane otpadne vode iz tekstilne industrije zagađene bojama BY 28 i AB 111 u mikroreaktorskim sistemima.

\section{Eksperiment}

Obezbojavanje uzoraka koji po sadržaju sintetske boje simuliraju veoma zaprljanu otpadnu vodu iz tekstilne industrije izvedeno je u mikroreaktorskom sistemu u čijem sklopu su dve pumpe LC20AD XR, Shimadzu Usa Manufacturing Inc koje su povezane sa kapilarnim mikroreaktorima. 
Mikroreaktorski sistemi su sastavljeni od kapilara izrađenih od hemijski otpornog polimera visokih performansi, poli-etar-etar-ketona (PEEK). Izlazi iz pumpi su povezani sa kapilarama prečnika 0,5 $\mathrm{mm}$ koje povezane sa $\mathrm{T}$ mikserom. Za potrebe eksperimenta korišćen je komercijalno dostupan rastvor $\mathrm{NaClO}$ proizvođača Alstman, Beograd kome je titracijom utvrđena koncentracija od 1 mas \%. Rastvor je za potrebe eksperimenta dodatno razblažen. Uzorci simulirane otpadne vode iz tekstilne industrije napravljeni su tako da koncentracije boje, kao zagađujuće materije odgovaraju veoma zaprljanim vodama iz tekstilne industrije. Rastvori su napravljeni rastvaranjem BY 28 i AB 111 u demineralizovanoj vodi (Milipore Waters Milli Q). Koncentracija obe boje bila je $0.130 \mathrm{mmol} / \mathrm{dm}^{3}$.

$\mathrm{Na}$ kraju sistema reakciona smeša je prihvatana u laboratorijske viale odgovarajućih zapremina. Reakcija je zaustavljana razblaženim rastvorom vodonik-peroksida koji ima ulogu inhibitora reakcije tako da je sastav uzorka pri merenju bio nepromenjen u odnosu na prihvaćeni uzorak u trenutku izlaska iz reaktora. Obezbojavanje rastvora praćeno je spektrofotometrijski (UV-Vis Shimadzu 1700) u vidljivom delu spektra na $438 \mathrm{~nm}$ za BY 28 i $634 \mathrm{~nm}$ za AB 111.

\section{$3 \quad$ Rezultati i diskusija}

Serije eksperimenata su izvođene pri konstantnim molskim odnosima reaktanata u promenljivom reaktorskom sklopu. Posledica promene sklopa i promene ukupnog protoka kojim se smeša u sistemu kreće je promena vremena zadržavanja reakcione smeše u sistemu. Dobijeni rezultati upoređeni su sa ranije dobijenim rezultatima obezbojavanja boje RO $16[10,11]$.

Slika 4 predstavlja zavisnost uspešnosti uklanjanja boje iz otpadne vode razblaženim rastvorom $\mathrm{NaOCl}$ pri molskom odnosu boje i NaOCl 3,35 u zavisnosti od vremena zadržavanja smeše u sistemu.

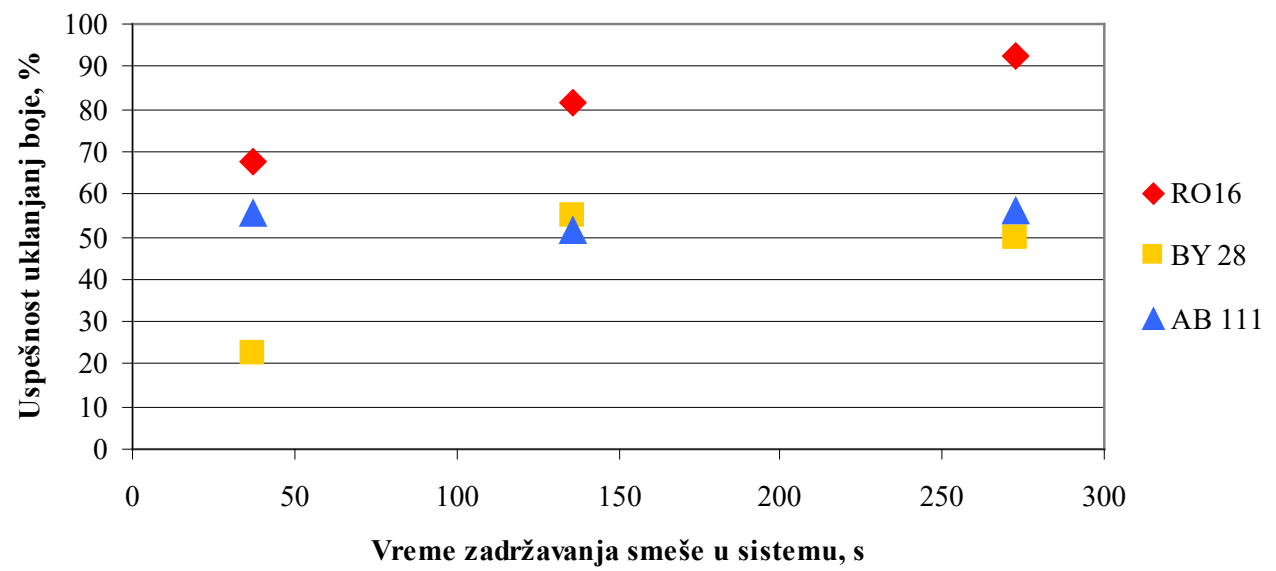

Slika 4. Uspešnost uklanjanja boje u zavisnosti od vremena zadržavanja reakcione smeše u sistemu

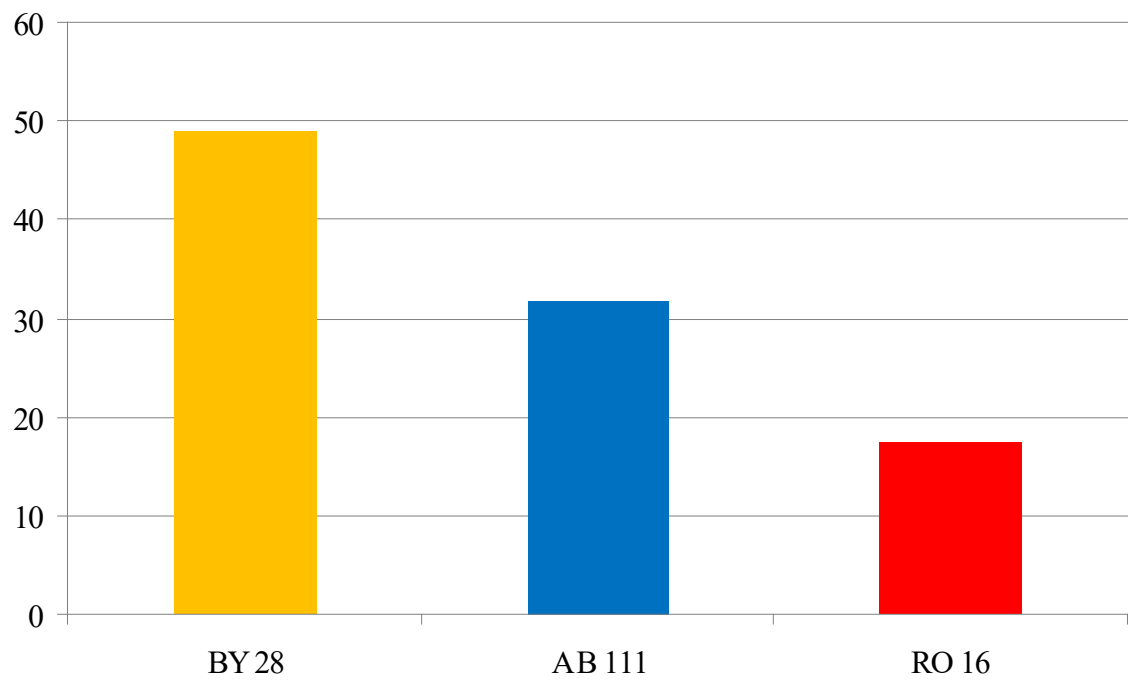

Slika 5. Uspešnost uklanjanja boje u procentima u reakcionim smešama pri molskom odnosu boje i NaOCl 2,23 za $B Y 28, A B 111$ i $R O 16$ 
Na slici 5 predstavljena je uspešnost uklanjanja boje u tri ekvimolarne smeše koje su obezbojavane $\mathrm{u}$ istom mikroreaktorskom sistemu pri istim protocima odnosno istim vremenima zadržavanja smeša u sistemu. Na primeru reakcionih smeša sa slike 5 je očigledno da pri molskom odnosu 2,23, protoku boje/rastvora $\mathrm{NaOCl}$ 0,3/0,1 $\mathrm{ml} / \mathrm{min}$ u mikroreaktorskom sistemu prečnika 0,5 i dužine $9,8 \mathrm{~m}$ obezbojavanje boje RO16 je daleko uspešnije nego u slučaju boja Basic Yellow 28 i Acid Blue 111.

Obezbojavanje sintetske boje u mikroreaktorskom sistemu, u slučaju boje RO 16 je veoma uspešno i to korišćenjem veoma razblaženog rastvora natrijum-hipohlorita. Boju je moguće ukloniti i potpuno, ali za to su potrebne veće koncentracije hipohlorita i sa stanovišta zaštite životne sredine, uklanjanje oko $80 \%$ prisutne boje je zadovoljavajuće jer je kvalitet te vode odgovarajući propisanom kvalitetu, npr. po sadržaju sintetske boje i hemijskoj potrebi kiseonika, za ispuštanje u vodoprijemnike [12].

\section{$4 \quad$ Zaključak}

U ranijim radovima autora prikazana je odlična uspešnost obezbojavanja simulirane otpadne vode iz tekstilne industrije opterećene sintetskom bojom RO 16 korišćenjem veoma razblaženih rastvora natrijum-hipohlorita u mikroreaktorskim sistemima. Otpadna voda prečišćena na ovaj način zadovaoljava kriterijume o kvalitetu vode, pa je ovako prečišćenu otpadnu vodu iz tektilne industrije dozvoljeno ispustiti u vodoprijemnik. Obezbojavanje u mikroreaktorskim sistemima boje AB 111 takođe uspešno ali ne koliko i obezbojavanje RO 16 sa veoma razblaženim rastvorima $\mathrm{NaOCl}$. Obezbojavanje vode sa bojom BY 28 bilo je bez tako velikog uspeha. Razlog je razlika u hemijskim reakcijama, odnosno različitim tipovima boja. Anjonsku azo boju RO 16 je moguće obezbojiti ovim putem dok se hemijske reakcije sa antrahionskom bojom AB 111 i katjonskom azometilenskom bojom BY 28 ne odigravaju sa tako velikim uspehom u mikroreaktorskim sistemom korišćenjem veoma razblaženih rastvora $\mathrm{NaOCl}$. Za obezbojavanje ove dve boje potrebno je koristiti rastvore hipohlorita većih koncentracija kako bi se postigao zadovoljavajući stepen obezbojavanja što bi za posledicu imalo dodatno zagađenje otpadne vode neproregovalim količinama hipohlorita i ovakva voda ne bi ispunjavala postavljene zahteve za kvalitet vode i ne bi mogla da se ispusti u vodoprijemnik pa izvodimo zaključak da je korišćenje mikroreaktorskih sistema neopravdano u slučaju uklanjanja boja AB 111 i BY 28 u mikroreaktorskom sistemu.

\section{Zahvalnica}

Istraživanja u ovom radu izvršena su u okviru aktivnosti na projektu TR 34009 i TR 1653014 koji finansira Ministarstvo prosvete, nauke i tehnološkog razvoja Republike Srbije.

\section{$5 \quad$ Literatura}

[1] Šekuljica, N. Ž., Enzimsko obezbojavanje antrahionskih boja iz otpadnih voda, doktorska teza, Univerzitet u Beogradu, Beograd, Srbija, 2016,

[2] S.W. Puasa, Ruzitah, M.S., Sharifah, A.S.A.K., Competitive removal of Reactive Black 5 / Reactive Orange 16 from aqueous solution via Micellar-enhanced Ultrafiltration, International Journal of Chemical Engineering and Applications, 3 (2012) 354-358. doi:10.7763/IJCEA.2012.V3.217.

[3] D. Mijin, Zlatic, D., Uscumlic, G., Jovancic, P., Solvent effects on photodegradation of CI Reactive Orange 16 by simulated solar light. Hem. Ind. 62 (2008) 275-281. doi:10.2298/HEMIND0805275M.

[4] D.B. Ward, Tizaoui, C., Slater, M.J., Wastewater dye destruction using ozone-loaded VolasilTM245 in a continuous flow liquid-liquid/ozone system. Chem. Eng. Process. Process Intensif. 45 (2006) 124-139. doi:10.1016/j.cep.2005.06.007.

[5] A. Spagni, Casu, S., Grilli, S., Decolourisation of textile wastewater in a submerged anaerobic membrane bioreactor. Bioresour. Technol. 117, 180-185. doi:10.1016/j.biortech.2012.04.074

[6] M. Radetic, Radojevic, D., Ilic, V., Mihailovic, D., Jovancic, P., Recycled wool-based nonwoven material for decolorisation of dyehouse effluents, Int. J. Cloth. Sci. Technol. 21 (2009) 109-116. doi:10.1108/09556220910933835 
[7] A.K. Verma, Dash, R.R., Bhunia, P., A review on chemical coagulation/flocculation technologies for removal of colour from textile wastewaters, J. Environ. Manage. 93 (2012) 154 168. doi:10.1016/j.jenvman.2011.09.012

[8] A. Alinsafi, Khemis, M., Pons, M.N., Leclerc, J.P., Yaacoubi, A., Benhammou, A., Nejmeddine, A., Electro-coagulation of reactive textile dyes and textile wastewater, Chem. Eng. Process. Process Intensif. 44 (2005) 461-470. doi:10.1016/j.cep.2004.06.010

[9] L. Gomes, Miwa, D.W., Malpass, G.R.P., Motheo, A.J., Electrochemical degradation of the dye reactive orange 16 using electrochemical flow-cell, J. Braz. Chem. Soc. 22, (2011) 12991306. doi:10.1590/S0103-50532011000700015

[10] A. Dajić, Mijin D., Grgur B., Mihajlović M., Jovanović M., „Obezbojavanje otpadnih voda iz tekstilne industrije korišćenjem cevnih mikroreaktora", 28.međunarodni kongres o procesnoj industriji Procesing '15, 4-5. juni, 2015, Inđija, Srbija, 978-86-81505-77-9, pp. 1-6.

[11] A. Dajić, Stevanović D., Karanac M., Mihajlović M., Jovanović J., Mijin D., Jovanović M., „Primena mikroreaktorskih sistema u zaštiti životne sredine: obezbojavanje otpadnih voda" 27.međunarodni kongres o procesnoj industriji Procesing'14, 22- 24 septembar, 2014, Beograd Srbija, 978-86-81505-75-5, pp. 1-6.

[12] Uredba o graničnim vrednostima emisije zagađujučih materija u vode i rokovima za njihovo dostizanje, Sl. glasnik RS", br. 67/2011, 48/2012 i 1/2016 